\title{
Prospective risk analysis of the anti-infective medication administration process ${ }^{1}$
}

\author{
Ana Elisa Bauer de Camargo Silva² \\ Silvia Helena De Bortoli Cassiani ${ }^{3}$
}

Objective: The objective of this study was to analyze the potential risks involved in the administration process of intravenous anti-infective medication at a medical clinic, using the Failure Mode and Effect Analysis. Method: This exploratory study was conducted at the medical clinic of a hospital in the State of Goiás. For data collection we convened a team comprised of six professionals involved in medication treatment: a doctor, nurse, nursing technician, pharmacist, a nursing and a risk manager. A total of 24 meetings were held, for a total of 56 hours. The data were transcribed into an electronic database within Microsoft Excel ${ }^{\circledR}$, and the Xfmea4 software was used. Result: The results indicated 52 failure modes, 79 effects of failure, and 285 causes of failure. The causes were related to: the management of organizational processes, human resources, physical and material structure. A total of 298 actions for improvement were recommended for 215 causes of high and average priority, 81.9\% of which were short-term priorities. The simulation of the impact of the proposed interventions revealed a $79.7 \%$ reduction of the high-priority failure modes. Conclusion: It was concluded that the study identified potential risks to patients and recommended proactive actions, of rapid application and low cost, evaluated positively in the reduction of risk of occurrence of avoidable incidents, increasing reliability and safety of the medication administration process. Studies like this demonstrate that, with the application of a method of risk analysis, nurses can effectively assist in preventing medication incidents.

Descriptors: Medication Errors; Quality of Health Care; Safety Management; Nursing; Patient Safety.

\footnotetext{
${ }^{1}$ Paper extracted from Doctoral Dissertation "Análise de risco do processo de administração de medicamentos por via intravenosa em pacientes de um Hospital Universitário de Goiás", presented to Escola de Enfermagem de Ribeirão Preto, Universidade de São Paulo, WHO Collaborating Centre for Nursing Research Development, Brazil. This research was supported by Conselho Nacional de Desenvolvimento Científico e Tecnológico (CNPq), process \# 870282/1997-2 and Coordenação de Aperfeiçoamento de Pessoal de Nível Superior (CAPES).

2 PhD, Professor, Faculdade de Enfermagem, Universidade Federal de Goiás, Brazil.

${ }^{3}$ PhD, Full Professor, Escola de Enfermagem de Ribeirão Preto, Universidade de São Paulo, WHO Collaborating Centre for Nursing Research Development, Brazil.
} 


\section{Análise prospectiva de risco do processo de administração de medicamentos anti-infecciosos}

Objetivo: este estudo teve o objetivo de analisar os riscos potenciais do processo de administração de medicamentos anti-infecciosos, por via intravenosa, de uma unidade de clínica médica, utilizando o método de análise do modo e efeito da falha. Método: de natureza exploratória, foi realizado na clínica médica de um hospital do Estado de Goiás. Para a coleta dos dados, foi constituída uma equipe composta por seis profissionais envolvidos na terapêutica medicamentosa: médico, enfermeiro, técnico de enfermagem, farmacêutico e os gerentes de enfermagem e de risco. Foram realizadas 24 reuniões, totalizando 56 horas. Todos os dados foram transcritos para um banco eletrônico, no programa Microsoft Excel ${ }^{\circledR}$ e analisados no software Xfmea4. Resultados: os resultados indicaram 52 modos da falha, 79 efeitos da falha e 285 causas da falha. As causas estavam relacionadas à gestão dos processos organizacionais, recursos humanos, estrutura física e material. Foram recomendadas 298 ações de melhorias para 215 causas de alta e média prioridade, sendo $81,9 \%$ de curto prazo. A simulação do impacto das ações propostas possibilitou identificar redução de $79,7 \%$ dos modos de falha de alta prioridade. Conclusão: conclui-se que o estudo identificou riscos potenciais para os pacientes e recomendou ações proativas, de rápida aplicação e baixo custo, avaliadas positivamente na redução do risco de ocorrência de incidentes evitáveis, aumentando a confiabilidade e segurança do processo de administração de medicamentos. Estudos como este comprovam que, com a aplicação de um método de análise de risco, os enfermeiros podem auxiliar efetivamente a prevenção de incidentes na medicação.

Descritores: Erros de Medicação; Qualidade da Assistência à Saúde; Gerenciamento de Segurança; Enfermagem; Segurança do Paciente.

\section{Análisis prospectivo de riesgo del proceso de administración de medicamentos anti-infecciosos}

Objetivo: Este estudio objetivó analizar los riesgos potenciales de administración de medicamentos anti-infecciosos por vía endovenosa en una unidad de Clínica Médica, utilizando el Método de Análisis del Modo y Efecto de Falla. Método: De naturaleza exploratoria, se realizó en la Clínica Médica de un Hospital del Estado de Goiás. Datos recolectados por equipo constituido por seis profesionales involucrados en la terapéutica medicamentosa: médico, enfermero, técnico de enfermería, farmacéutico y gerentes de Enfermería y de riesgo. Fueron efectuadas 24 reuniones, totalizándose 56 horas. Todos los datos fueron transcriptos a un banco, utilizando planilla de cálculo de Microsoft Excel ${ }^{\circledR}$ y analizados con software Xfmea4. Resultado: Los resultados indicaron 52 modos de falla, 79 efectos de la falla y 285 causas de falla. Las causas se relacionaron con la gestión de procesos organizacionales; recursos humanos; estructura física y material. Fueron recomendadas 289 acciones de mejora para 215 causas de alta y media prioridad, $81,9 \%$ de corto plazo. La simulación del impacto de las acciones propuestas posibilitó identificar una reducción de 79,7\% de los modos de falla de alta prioridad. Conclusión: Se concluye en que el estudio identificó riesgos potenciales para los pacientes y recomendó acciones proactivas, rápidamente aplicables y de bajo costo, evaluadas positivamente en la reducción del riesgo de ocurrencia de incidentes evitables, aumentando la confiabilidad y seguridad del proceso de administración de medicamentos. Estudios como éste comprueban que, con la aplicación de un método de análisis de riesgo, los enfermeros pueden colaborar activamente en la prevención de incidentes en la administración de medicamentos.

Descriptores: Erros de Medicación; Calidad de la Atención de Salud; Administración de la Seguridad; Enfermería; Seguridad del Paciente.

\section{Introduction}

Anti-infective medications are developed in order to be the most toxic toward the microorganisms and, at the same time, the safest for human cells
(1). Unnecessary or inadequate use is associated with the emergence of antimicrobial resistance, toxicity, increased morbidity and high cost of health care ${ }^{(2)}$. 
This type of medicine has been involved in incidents relating to patient safety ${ }^{(3)}$.

In Spain, a study identified that of 2,696 hospitalized patients, $173(6.4 \%)$ suffered a medication incident, of which 34 were errors involving anti-infectives ${ }^{(4)}$. Multicenter studies conducted in Brazilian hospitals have also identified a high prevalence of incidents with antimicrobials. In one of these, $8.4 \%$ of dosage errors involved antimicrobials. In another, 1,500 errors were identified, of which $18.5 \%$ involved antimicrobials. The most frequent errors were those related to timing $(87.7 \%)$ and dosage $(6.9 \%)^{(5)}$.

In Goiás, a study conducted in a medical clinic unit verified the occurrence of 230 medication errors (ME); the antiinfectives had the second highest incidence, with $66.5 \%$ of errors involving those infused by the parenteral route ${ }^{(6)}$.

Medication incidents occur independent of the route of administration, however the intravenous (IV) route exposes the patient to a higher risk. A Spanish study verified that $50 \%$ of ME occurred when the IV route was utilized. In an Australian hospital, 293 patients incidents were reported, with $24 \%$ related to medications; of those, $35 \%$ related to the IV route ${ }^{(7)}$.

In addition to damages caused to patients, ME are estimated to cost heath institutions more than four million dollars per year, due to increased length of stay and care provided to patients ${ }^{(8)}$. Thus, researchers, health institutions and professionals need to develop intervention actions aimed toward minimization and correction of risks, in order to prevent medication incidents.

Considering that the risks correspond to the occurrence and severity of an adverse event on the patient's health, the utilization of risk analysis methods can provide knowledge about existing problems, to detect risks in care, to determine root causes and to propose corrective and preventive measures, which are accurate and timely. Among the existing methods, the Failure Mode and Effect Analysis (FMEA) is characterized by its proactive, prospective, non-statistical and systematic nature ${ }^{(9-10)}$.

The FMEA has been recommended by international organizations, such as the Joint Commission, Institute for Healthcare Improvement, and the Institute for Safe Medication Practices, to identify and analyze failure modes of care processes, their effects and causes, to establish priorities and to outline recommendations directed at eliminating or reducing the possibility of failure occurrence ${ }^{(10-13)}$.
Given the above, we envisioned the opportunity to develop a study by which there was a real and direct action in the process of medication administration performed by nurse. From this perspective, this study analyzed the risks of the process of administering antiinfective agents medications intravenously, to identify the Potential Failure Modes (PFM), the Potential Effect(s) of Failure (PEF), the Potential Cause(s) of Failure (PCF) and the existing controls, aimed toward recommending actions for improvement, in order to promote better quality and safety in nursing care.

\section{Method}

This was an exploratory study, conducted in a medical clinic unit of a teaching hospital in the State of Goiás. The hospital had 317 beds, exclusively for patients of the national health system, the Sistema Unico de Saude (SUS) and, since 2002, it was integrated into the National Network of Sentinel Hospitals of the National Vigilance Agency, Rede Nacional de Hospitais Sentinela da Agência Nacional de Vigilância (ANVISA).

The inpatient unit in question had a capacity of 59 beds, distributed across thirteen wards with beds allocated for the various specialties, and it was selected because there were hospitalized patients with chronic degenerative diseases who, usually, utilized a large and varied range of medications in their treatment.

The research was conducted after approval by the Committee of Ethics in Research (Case No. 096/2004) and the steps recommended by the FMEA method were followed(9).

Therefore, to perform the analysis of the intravenously infused, anti-infective medication administration process, standardized in the unit studied, a multidisciplinary team was initiated, composed of six professionals who worked in medication therapy at the institution: the risk manager, a doctor, two nurses, one of whom was the manager of the unit, a nursing technician, and a pharmacist. Managers were invited, considering their importance in the effectiveness of possible improvement actions. The doctor was indicated by the clinical director of the the hospital unit. For the selection of nursing professionals, the nursing unit manager was asked to indicate two professionals, one nurse and one nursing technician, who would demonstrate proactive attitudes in the search for improvements in service quality. Based on the indications of the managers, the invitation was given to the professionals who, after confirming their availability and interest in participating 
in the study, signed the Terms of Free and Informed Consent, according to the current regulations in the country ${ }^{(14)}$.

In order to address the objective of the research, 24 team meetings were necessary, totaling 56 hours, which occurred from February to July of 2008. All data coming from the FMEA were recorded on a spreadsheet.

After validation of typing by double data entry, the database was transferred to the software, Xfmea 4, which performed the analysis and generated reports and graphs. Data are presented in descriptive form by means of tables and graphs.

\section{Results}

The administration process of intravenous anti-infective medications was composed of four micro-processes (1. pre-preparation; 2. medication preparation; 3. Medication administration; 4. postadministration), in which ten activities and 22 functions were involved, performed by nursing professionals.

The activities identified in the process were: 1) Forward the prescription medications and control forms to the medicine station; 2) Schedule the prescribed medications; 3) Transcribe the labels for the prescription medications; 4) Forward the duplicate medical prescriptions and control forms to the hospital pharmacy; 5) Receive and package the medications and materials supplied by the hospital pharmacy; 6) Prepare medications; 7) Administer medications; 8) Monitor the administration of medications and patient reactions, 9) Record and document the administration of medications; 10) Return unused medicines.
The risk analysis identified 52 PFM, i.e., faults that may occur during the process of medication administration that pose a risk to the safety of patients, with the largest number of these in the stage of prepreparation with 19 (36.5\%) PFM, and in the step of medication administration with 16 (30.8\%) PFM. The preparation of medicines had 12 (23.1\%) PFM, and the post-administration had $5(9.6 \%)$ PFM.

The greatest number of PFM was identified in the activity of administering medications, in which sixteen (30.8\%) PFM were identified. Following this, the activity that presented more opportunities for failures was the preparation of medications, with twelve (23.1\%).

The analysis of these ten activities allowed for the identification of $79 \mathrm{PEF}$, of which $66.2 \%$ were of medium severity, i.e., requiring monitoring, specialized assessment, and application of other medications to reverse the damage, interfering in the basic treatment with prolongment of the hospitalization; and $27.5 \%$ of high severity, which required an intervention in order to maintain the patient's life.

The three most common types of PEF were technical errors $(21 ; 26.6 \%)$, omission (20; 25.3\%), and the administration time $(15 ; 19 \%)$, and they were more frequent in the pre-preparation $(35 ; 44.3 \%)$ and medication administration $(24 ; 30.4 \%)$ stages.

The FMEA enabled the identification of 285 PCF, which were categorized by similarity in content, making possible the identification of three categories related to: management of organizational processes $(125 ; 43.9 \%)$, human resources $(124 ; 41.4 \%)$; physical structure and material (12.6\%), as shown in Table 1.

Table 1 - Distribution of categories of Potential Failure Causes according to subcategory, activity and frequency. Goiânia, GO, Brazil, 2008

\begin{tabular}{|c|c|c|c|c|c|c|c|c|c|c|c|c|}
\hline \multirow{2}{*}{ Potential Causes of Failure } & \multicolumn{10}{|c|}{ Activity } & \multicolumn{2}{|c|}{ Frequency } \\
\hline & 1 & 2 & 3 & 4 & 5 & 6 & 7 & 8 & 9 & 10 & $\mathrm{n}$ & $\%$ \\
\hline Category B - Management of the organizational processes & & & & & & & & & & & 125 & 43.9 \\
\hline $\begin{array}{l}\text { Inexistence of routines, protocols, procedures and } \\
\text { standardization }\end{array}$ & 4 & 2 & 2 & & 5 & 11 & 22 & 2 & 1 & & 49 & 17.2 \\
\hline Lack of continuing education & & & & & & 3 & 17 & 2 & 1 & & 23 & 8.1 \\
\hline Work overload & 4 & 3 & 9 & 6 & 3 & 12 & 13 & 2 & 1 & & 53 & 18.6 \\
\hline Category A - Human Resources & & & & & & & & & & & 124 & 41.4 \\
\hline Deficient knowledge & 4 & 1 & & & & 6 & 7 & 1 & 1 & & 20 & 7 \\
\hline Skills & & & 11 & & 1 & 16 & 20 & & & 1 & 49 & 17.2 \\
\hline Lack of attention & 4 & 1 & 10 & 6 & 3 & 12 & 17 & & 2 & & 55 & 19.3 \\
\hline Category C - Physical and material structure & 15 & 6 & 3 & 5 & 7 & & & & & & 36 & 12.6 \\
\hline Total & 31 & 13 & 35 & 17 & 19 & 60 & 96 & 7 & 6 & 1 & 285 & 100 \\
\hline
\end{tabular}


Among the controls, potentials of preventing or detecting failure modes, 211 of detection were identified, which means rework and cost to the organization, and only 12 of prevention. Many were circumstances that could function as detection alerts, such as the yellow color of the duplicate prescription, detaching it from the rest of the patient slip, indicating to the health team that it was not sent to the pharmacy. Due to the lack of controls or controls with minimal power of detection and prevention, 189 (66.3\%) of the PCF had zero possibility of being detected.

For an overview of the FMEA, the absolute and relative frequency of the functions of PFM, PEF and PCF, as well as the indices of severity of the PEF (G), the occurrence of PCF (O) and the probability of detection (D), are presented in Table 2.

Table 2 - Distribution of functions, modes, effects, causes and controls of potential failure, according to activity, and frequency rates. Goiania, GO, Brazil, 2008

\begin{tabular}{|c|c|c|c|c|c|c|c|c|c|c|c|c|c|}
\hline \multirow{2}{*}{ Activity } & \multicolumn{2}{|c|}{ function } & \multicolumn{2}{|c|}{ PFM } & \multicolumn{3}{|c|}{ PEF } & \multicolumn{3}{|c|}{ PCF } & \multicolumn{3}{|c|}{ Controls } \\
\hline & $n$ & $\%$ & $n$ & $\%$ & $\mathrm{n}$ & $\%$ & G & $\mathrm{n}$ & $\%$ & 0 & n & $\%$ & D \\
\hline 1 & 2 & 9 & 2 & 3.8 & 4 & 4 & 5,7 & 16 & 5.6 & 1 & 16 & 5.6 & 4,10 \\
\hline 2 & 1 & 4.5 & 5 & 9.6 & 5 & 6.3 & $3,5,6,7$ & 7 & 2.5 & $1,4,7,9$ & 7 & 2.5 & $6,9,10$ \\
\hline 3 & 2 & 9 & 5 & 9.6 & 13 & 16.3 & $5,6,7$ & 47 & 16.5 & $\begin{array}{l}1,2,3,4 \\
6,7,9,10\end{array}$ & 47 & 16.5 & $3,5,10$ \\
\hline 4 & 2 & 9 & 3 & 5.8 & 6 & 7.5 & 5,7 & 18 & 6.3 & $4,8,9$ & 18 & 6.3 & 8,9 \\
\hline 5 & 1 & 4.5 & 4 & 7.7 & 8 & 10 & $5,6,7$ & 15 & 5.3 & $\begin{array}{c}3,4,6,7 \\
8,9\end{array}$ & 15 & 5.3 & 8,10 \\
\hline 6 & 4 & 18.2 & 12 & 23.1 & 15 & 18.7 & $5,6,7,9$ & 64 & 22.5 & $\begin{array}{c}1,2,3,4 \\
5,6,7,10\end{array}$ & 64 & 22.4 & $\begin{array}{l}6,7 \\
9,10\end{array}$ \\
\hline 7 & 5 & 22.7 & 16 & 30.8 & 24 & 30 & $5,6,7$ & 104 & 36.5 & $\begin{array}{c}1,2,3,4,5 \\
7,8,9,10\end{array}$ & 104 & 36.5 & $4,8,10$ \\
\hline 8 & 2 & 9 & 2 & 3.8 & 2 & 2.5 & 4,5 & 7 & 2.5 & $\begin{array}{c}3,5,8,9 \\
10\end{array}$ & 7 & 2.5 & 10 \\
\hline 9 & 1 & 4.5 & 2 & 3.8 & 2 & 2.5 & 6,7 & 6 & 2.1 & 3,7 & 6 & 2.1 & 10 \\
\hline 10 & 2 & 9 & 1 & 1.9 & 1 & 1.25 & 6 & 1 & 0.3 & 9 & 1 & 0.35 & 10 \\
\hline Total & 22 & 100 & 52 & 100 & 80 & 100 & & 285 & 100 & & 285 & 100 & \\
\hline
\end{tabular}

The 285 PCF had their Risk Priority Numbers (RPN) calculated by means of multiplication of the values of severity, occurrence and detection, ranging from one to ten and, thus, the RPN ranged between 10 and 700 . The FMEA team determined that the RPN score of up to 100 would be considered low priority risk; those between 101 and 300 would be medium priority, and RPN scores between 301 and 700 would be a high priority. It was also defined that the recommendations of improvement actions would be made for the 215 PCF with an RPN of high risk $(59 ; 20.7 \%)$ and medium risk $(156 ; 54.7 \%)$.

In total, 298 actions were recommended for improving the process for the 10 activities realized, with $244(81.9 \%)$ of short-term (six months), 40 (13.4\%) of medium (from six months to two years) and $14(4.7 \%)$ of long-term (over two years).

Among the recommendations were actions of continuing education (84; 28.5\%); guidelines for professionals $(54 ; 18.3 \%)$; replanning and redistribution of nursing activities aiming at reduction in work overload ( $34 ; 11.5 \%)$. Also proposed were: preparation of medicine based on the prescription and not on the transcribed labels; development of standards, manuals, and protocols; checklists; identification of beds and patients with bracelets in different colors for special cases such as allergies; and the utilization of alerts on beds of patients in the same ward, with similar or identical names and computerization of the identification label of the medication.

Following the recommendation of the actions of intervention, through a process of simulation done by the FMEA team, new scores were estimated for the occurrence and detection of PCF and, therefore, the RPN were reviewed. The RPN before the improvements was named the RPN Initial (RPNI), and the RPN after the improvements was named the RPN Revised (RPNr).

The impact of the recommended actions on the RPN of the 215 PCF, of the 46 PFM, could be seen in all the process activities analyzed, with the largest reduction in RPN (90\%) taking place in activity 3, as shown in Figure 1. 
Activities classified by the \% reduction of RPN (1-9)

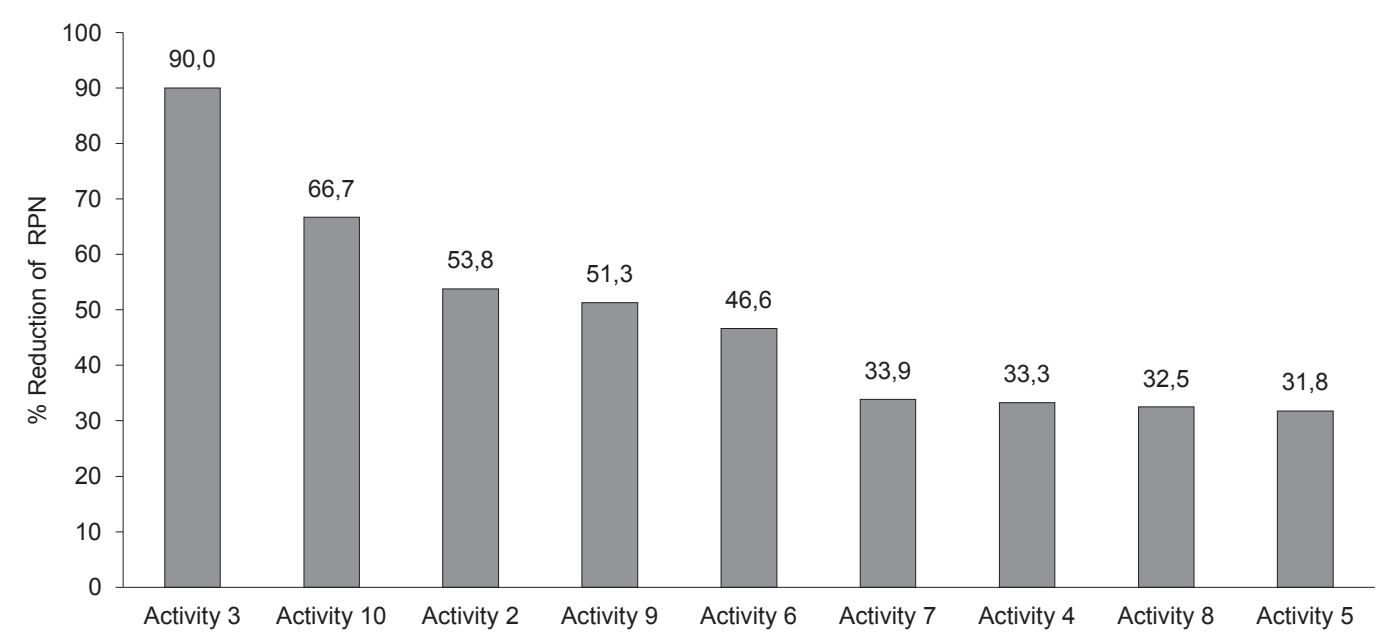

Figure 1 - Distribution of the percentage of reduction in the Risk Priority Number (RPN) after simulation of the effectiveness of the improvement actions. Goiania, GO, Brazil, 2008.

The final analysis of the results also identified that the PCF with high and medium priority risk decreased and those with low priority increased, as shown in Table 3.

Table 3 - Distribution of potential causes of failure according to the priority level of risk before and after the recommended actions. Goiania, GO, Brazil, 2008

\begin{tabular}{|c|c|c|c|c|c|c|}
\hline \multirow{2}{*}{ Level of risk priority of PCF } & \multicolumn{2}{|c|}{ Before actions } & \multicolumn{2}{|c|}{ After actions } & \multirow{2}{*}{ Reduction (\%) } & \multirow{2}{*}{ Increase (\%) } \\
\hline & $\mathbf{n}$ & RPN & $\mathbf{n}$ & RPN & & \\
\hline High RPN & 59 & $700-315$ & 12 & $450-315$ & 79.7 & \\
\hline Medium RPN & 156 & $300-105$ & 147 & $300-108$ & 5.8 & \\
\hline Low RPN & 70 & $100-10$ & 126 & $100-10$ & & 80 \\
\hline Total & 285 & & 285 & & & \\
\hline
\end{tabular}

\section{Discussion}

The analysis of the administration process of intravenous route medications made it possible to understand its complexity and scope, to identify that there are several microprocesses inserted and interconnected and interrelated activities, performed by several professionals that, many times, elapse simultaneously.

The FMEA enabled the identification of 52 potential failure modes in the process. Traditionally, it had been thought that the majority of failures happen because of human fault and thus, the processes are developed within the premise that nothing will go wrong, which this study has shown to be untrue.

Among the potential effects of failure, $44.3 \%$ of these were errors of omission and of time. The errors of omission and time, when you focus on the antibacterial class, may influence the therapeutic effectiveness and the bacterial resistance, considering that the latter is associated with the inappropriate use of these medications ${ }^{(5)}$.

When there is omission, regardless of the number of doses of antibacterials that are not administered, it should be considered that this error may lead to plasma concentrations below the minimum inhibitory concentration, exerting selective pressure on the microorganism, a risk factor for the development of microbial resistance ${ }^{(5,15)}$.

The time errors have as potential causes problems in scheduling, which should be designed so that there is not a concentration of a high number of medications in a specified period, to ensure that those requiring timely administration, such as anti-infectives, have their timing requirements met $^{(5)}$. 
With regard to the understanding from the 285 potential causes of failure considered, the management of organizational processes and physical and material structure can be considered within the systemic approach to failures. This approach understands that humans are fallible and that incidents should be expected, even in the best organizations. Therefore, the analysis is made that may contribute to the occurrence of the failure: management of human and financial resources; the presence and utilization of standards; conditions of the work environment; verification of the work overload of professionals and operating conditions of the equipment ${ }^{(16)}$.

The potential causes of failures related to physical structure and material referred to environmental conditions, such as desorganization and frequent interruptions during procedures. Working under adverse conditions can lead humans to commit errors, so it is imperative that nursing participate in the organizational decisions, including those related to the construction or renovation of work environments, aiming at improving environmental conditions and the resources utilized(17).

In relation to the potential causes of failures directed to the human resources, there was no surprise identified in this category, because the lack of attention was most frequently cited by the team $(55 ; 19.3 \%)$. The existing culture in healthcare organizations is still very much focused on the professionals' responsibility for the incidents, to the detriment of management, structural and procedural faults. The individual approach as an explanation of the flaws and errors treats the problem in a simplistic manner, as the person responsible for failure is found, punished and the investigation is closed, with no improvements in process.

The fact of the higher frequency of recommendations to be directed towards Continuing Education and guidance for professionals allows the inference that the multidisciplinary team, involved in the study, also brought with it a personal belief that the medication incidents were the result of individual failures. However, it is known that the analysis of the causes of adverse events that occur related to care reveals a connection with deficits in knowledge of the healthcare team and, also, of performance, making it necessary to review the quality of the training of the professionals and the introduction and maintenance of continuing education in health care institutions ${ }^{(18)}$.

We must add that ignorance, on the part of nursing about basic pharmacological aspects can induce errors such as to failure to observe the need for administration of the exact dose necessary and at the correct time for each patient, and may generate many clinical consequences ranging from the absence of response to intolerable toxicity ${ }^{(3)}$.

It is highlighted that recommendations were also made of replanning and redistribution of the activities of nursing aimed at reducing work overload. The reduced number of nurses, increased workload and the existence of unstable environments contribute to negative outcomes and undesirable patient care, such as falls and medication errors in medical and surgical units( ${ }^{(17)}$.

In relation to recommendations for standardization and protocols, it is noteworthy that the adoption of standardization in verification of medical prescriptions, by the pharmacists, and the development of a protocol for the medication delivery carts for inpatient units, in a Spanish hospital after FMEA, decreased by $56.9 \%$ errors such as extra doses and $41.6 \%$ of errors of

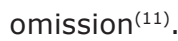

\section{Conclusion}

The study allowed the recognition of the administration process of anti-infective medications by the intravenous route, identified potential risks to hospitalized patients, and recommended actions, positively evaluated for their potential to reduce the risk of preventable medication incidents and increase reliability in the process. Increasing the reliability of this process is necessary and can be considered an advance toward improving the quality of care provided.

The process of medication administration is complex and performed daily in all hospitals, with high chances of risk to patients. In this investigation it was possible to identify 52 faults in the process with the potential to cause $66.2 \%$ effects of average severity in patients admitted and receiving intravenous antiinfectives. Recommended strategies were proactive, considered simple, of rapid implementation, and were not dependent on an organizational decision for their enforcement. This corresponded to the creation of barriers, increasing the safety of the medication administration process.

There is consensus that the adoption of a method, alone, does not guarantee the quality of care, however, this study enabled us to demonstrate that the application of a method of risk analysis can be used successfully by nurses in the prevention of avoidable medication incidents. 


\section{Referências}

1. Rang HP, Dale MM, Ritter JM, Flower RJ. Farmacologia. $2^{a}$ tiragem. 6a. ed. Rio de Janeiro: Elsevier; 2007. 829 p.

2. Cusini A, Rampini SK, Bansal V, Ledergerber B, Kuster SP, Ruef C, et al. Different Patterns of Inappropriate Antimicrobial Use in Surgical and Medical Units at a Tertiary Care Hospital in Switzerland: A Prevalence Survey. PLoS ONE [Internet]. 2010 [acesso 21 ago 2012];5(11):e14011. Disponível em: http://www.plosone.org/article/ info\%3Adoi\%2F10.1371\%2Fjournal.pone.0014011

3. Gimenes FRE, Mota MLS, Teixeira TCA, Silva AEBC, Opitz SP, Cassiani SHB. Patient Safety in Drug Therapy and the Influence of the Prescription in Dose Errors. Rev. Latino-Am. Enfermagem. [periódico na Internet]. 2010 [acesso 13 set 2012];18(6): ):1055-61. Disponível em: http://www.scielo.br/pdf/rlae/v18n6/03.pdf

4. Menéndez MD, Corte J, Alonso M, Espín M, Solano J, Vázquez F. Errores en el uso de antimicrobianos: la epidemia silenciosa para la seguridad de pacientes. Rev Esp Quimioter [periódico na Internet]. 2008 [acesso 21 ago 2012];21(3):194-7. Disponível em: http://seq.es/ seq/0214-3429/21/3/menendez.pdf

5. Marques TC, Reis AMM, Silva AEBC, Gimenes FRE, Opitz SP, Teixeira TCA, et al. Erros de administração de antimicrobianos identificados em estudo multicêntrico brasileiro. Rev Bras Cienc Farm. [periódico na Internet]. 2008 [acesso 21 ago 2012];44(2):305-14. Disponível em: http://www.scielo.br/pdf/rbcf/v44n2/a16.pdf

6. Silva AEBC, Reis AMM, Miasso AI, Oliveira J, Cassiani SHB. Adverse drug events in a sentinel hospital in the state of Goiás, Brazil. Rev. Latino-Am. Enfermagem. [periódico na Internet]. 2011 [acesso 21 ago 2012];19(2):378-86. Disponível em: http://www.scielo. $\mathrm{br} / \mathrm{pdf} / \mathrm{rlae} / \mathrm{v} 19 \mathrm{n} 2 / 21 . \mathrm{pdf}$

7. Burdeu G, Crawford R, van de Vreede M, McCann

J. Taking aim at infusion confusion. J Nurs Care Qual [periódico na Internet]. 2006 [acesso 21 ago 2012];21(2):151-9. Disponível em: http://bmhlibrary. info/16540784.pdf

8. Paradis, A. R., Stewart, V. T., Bayley, K. B., Brown, A., Bennett A. J. Excess cost and length of stay associated with voluntary patient safety event reports in hospitals. Am J Med Qual. [periódico na Internet]. 2009 [acesso 13 set 2012];24(53):53-60. Disponível em: http://ajm. sagepub.com/content/24/1/53.long

9. Stamatis $\mathrm{DH}$. Failure mode and effect analysis: FMEA from theory to execution. 2nd. ed. Milwaukee, Winsconsin: ASQ, Quality Press; 2003. 494 p.
10. Raduenz AC, Hoffmann P, Radunz V, Dal Sasso GTM, Maliska ICA, Marck PB. Nursing Care and Patient Safety: Visualizing Medication Organization, Storage and Distribution with Photographic Research Methods. Rev. Latino-Am. Enfermagem. [periódico na Internet]. 2010 [acesso 13 set 2012];18(6):1045-54. Disponível em: http://www.scielo.br/pdf/rlae/v18n6/02.pdf

11. Vélez-Díaz-Pallarés $M$, Delgado-Silveira $E$, CarreteroAccame ME, Bermejo-Vicedo T. Using Healthcare Failure Mode and Effect Analysis to reduce medication errors in the process of drug prescription, validation and dispensing in hospitalised patients. BM] Qual Saf. [periódico na Internet]. 2012 [acesso 13 set 2012];0:1-11. Disponível em: http://qualitysafety.bmj.com/content/ early/2012/09/12/bmjqs-2012-000983.full.pdf+html

12. Bonfant G, Belfanti P, Paternoster G, Gabrielli D, Gaiter AM, Manes M, et al. Clinical risk analysis with failure mode and effect analysis (FMEA) model in a dialysis unit. J Nephrol. [periódico na Internet]. 2010 [acesso 21 ago 2012];23(1):111-8. Disponível em: http://www.jnephrol.com/public/JN/Article/Attach. action?cmd=Download\&uid=E196BEDC-2B34-4D468800-D27CBFB0E96E

13. Gilchrist M, Franklin BD, Patel JP. An outpatient antibiotic therapy (OPAT) map to identify risks associated with an OPAT service. J Antimicrobiol Chemother. [periódico na Internet]. 2008 [acesso 21 ago 2012];62(1):177-83. Disponível em: http://jac. oxfordjournals.org/content/62/1/177.full.pdf+html

14. Ministério da Saúde (BR). Conselho Nacional de Saúde. Comissão Nacional de Ética em Pesquisa. Resolução No. 196 de 10 de outubro de 1996: diretrizes e normas regulamentadoras de pesquisa envolvendo seres humanos. Brasília (DF): MS; 1996.

15. Hoefel HHK, Lautert L. Administração endovenosa de antibióticos e resistência bacteriana: responsabilidade da enfermagem. Rev Eletr Enferm. [periódico na Internet]. 2006 [acesso 21 ago 2012];8(3):441-9. Disponível em: http://www.fen.ufg.br/revista/revista8_3/v8n3a15.htm 16. Reason J. Human error. Cambridge, M.A.: Cambridge University Press, 2003. 301p.

17. Duffield C, Diers D, O'Brien-Pallas L, Aisbett C, Roche $M$, King M, Aisbett K. Nursing staffing, nursing workload, the work environment and patient outcomes. Applied Nurs Res. [periódico na Internet]. 2011 [acesso 13 set 2012];24:244-55. Disponível em: http://www.sciencedirect.com/science/article/pii/ S0897189709001311

18. Gimenes FRE, Marques TC, Teixeira TCA, Mota MLS, Silva AEBC, Cassiani SHB. Medication wrong-route 
administrations in relation to medical prescriptions.

Rev. Latino-Am. Enfermagem. [periódico na Internet].

2011 [acesso 13 set 2012];19(1):11-17. Disponível

em: http://www.scielo.br/scielo.php?script=sci_

arttext\&pid=S0104-11692011000100003\&Ing=pt\&nrm

=iso 